\title{
Communication for HIV/AIDS Prevention in Kenya: Social-Cultural Considerations
}

\author{
Nancy W. Muturi
}

\begin{abstract}
The acquired immune deficiency syndrome (AIDS) epidemic is spreading fast in Africa in spite of the various efforts and resources put in place to prevent it. In Kenya, reproductive health programs have used the mass media and other communication interventions to inform and educate the public about the disease and to promote behavior change and healthy sexual practices. This effort has led to a discrepancy between awareness and behavioral change among people of reproductive age. In this article I examine the discrepancy in Kenya from a communications perspective addressing social cultural and related factors contributing to the lack of change in behavior and sexual practices. I draw on the theoretical framework of Grunig's model of excellence in communication, the importance of understanding and relationship building between programs and their stakeholders. Data were gathered qualitatively using focus groups and in-depth interviews among men and women in rural Kenya. Key findings indicate that although awareness of sexually transmitted diseases (STDs) including human immunodeficiency virus (HIV)/AIDS is high in Kenya, a majority of the population, particularly those in the rural communities, lack understanding of the communicated messages. They also lack the knowledge of other ways of transmitting HIV particularly among those not sexually involved. Cultural beliefs, values, norms, and myths have played a role in the rapidly increasing epidemic in the rural communities and yet HIV/AIDS communication programs have not addressed these factors adequately. I conclude that successful behavior change communication must include strategies that focus on increasing understanding of the communicated messages and understanding of the audience through application of appropriate methodologies. Building a relationship with the audience or stakeholders through dialogues and two-way symmetrical communication contributes toward this understanding and the maintenance of the newly adopted behaviors and practices.
\end{abstract}

This paper was extracted from a Ph.D. thesis, University of Iowa. It was first presented at the Association for Journalism and Mass Communication (AEJMC) in Florida, August 2002.

How to cite this article:

Muturi, Nancy W. (2005). Cultural considerations in HIV/AIDS communication and prevention in Kenya. Journal of Health Communication, 10(1) 77-98 
Some people say that they can only get AIDS once and they cannot get infected again so they do not need to use any protection. If their partners insist on using a condom, they deliberately tear it off or slip it out in the process. They don't even care if their wife or girlfriend gets AIDS because they don't want to die alone. It makes me feel like everybody will die from AIDS because people try to give it to others on purpose. Like if a man with AIDS hates another man, he will try to give it to his [healthy man's] wife and children so that his family can suffer too. We need to know how to protect ourselves before we all die from it. (32-year-old rural woman)

The goal of health communication programs is to increase knowledge and understanding of health-related issues and to improve the health status of the intended audience. Understanding is important in achieving this goal, especially in situations where cultural values, beliefs, and practices continue to put people at risk. In human immunodeficiency virus (HIV)/AIDS prevention, effective communication is considered an integral part of service delivery programs to both providers and clients. In rural communities, for example, effective communication involves more than simply disseminating health messages using popular media or enhancing people's compliance with medical regimens. It goes beyond dissemination and involves interventions that deal with issues of participation and empowerment for proper decision making.

The main objective of this study is to examine some of the factors that influence Kenyan people's reproductive health decision to use (or not to use) contraceptives, particularly condoms, for preventing STDS including HIV/AIDS and other reproductive tract infections. Demographic and health surveys in Kenya and other studies indicate an awareness of modern contraceptive methods among married women of up to $98 \%$, but only one-third of those aware $(32 \%)$ are using contraceptives (Gule, 1994; National Council for Population and Development [NCPD], 1998; Westoff \& Rodriguez, 1995). It is also clear that most people who are aware of the consequences of unprotected sexual practices are not changing their behavior even in this era of the HIV/AIDS epidemic.

Everett Rogers (1995) referred to the discrepancy between awareness and behavior change as the knowledge, attitude, and practice (KAP) gap. In Africa, this gap primarily has been attributed to a lack of service availability and it has been used as a key rationale for expanding services, especially among rural women who are most often perceived as noncompliant (Wolff, Blanc, \& SsekamatteSsebuliba, 2000). Many reproductive health programs, for example, interpret the low contraceptive adoption rate as the "unmet need"1 for family planning, and the solution proffered consists of increasing quality contraceptive services. This includes distribution of condoms and making them available at low or no cost through social marketing and community-based distribution approaches.

Feminists and reproductive health advocates have taken a woman's perspective in addressing this discrepancy. Betsy Hartmann (1995), for example, challenges one of the core assumptions according to which "people can be motivated to practice healthy behavior through information, education, and communication (IEC) campaigns-e.g., through billboards, messages over the radio and cinema, or lectures in schools and public meetings" (p. 61). Hartmann argues that based on these assumptions many programs are typically beset with a number of problems and biases including the elitist bias, which often is reflected in the disseminated messages that frequently are inappropriate for the target audience. She also calls for women-centered strategies that aim at increasing understanding and addressing women's needs.

In response to such criticisms, Everett Rogers and other development and health communication scholars like Phyllis Piotrow and colleagues have called upon programs to use a more participatory communication approach where clients or the intended audience can participate more

\footnotetext{
${ }^{1}$ Unmet need is a situation where married women in developing countries express a desire to space or limit their births are not using any form of contraception (World Bank, 1996).
} 
actively at the decision-making level (Agunga, 1997; Ascroft \& Agunga, 1994; Piotrow, Kincaid, Rimon, \& Rinehart, 1997; Rogers, 1995). Others have advocated for client- or audience-centered communication strategies especially when targeting rural populations (Chambers, 1983). According to Chambers, this includes research methodologies used to gather information from these populations, especially the women. Reproductive health information, education, and communication is a basic human right that was recognized and affirmed at the 1994 and 1995 international population and women's conferences, respectively. This means that people have a right to reproductive health information, they have a right to make their own decisions regarding their sexual life based on this information, and that they have a socially enabled capacity to act on those decisions. To know, people must have the knowledge; to decide, they must have options; and to act, they must have access to services.

Most people, particularly women, however, are denied this right and the freedom to decide because of social-cultural and economic factors that impede their decisions in sexual and reproductive health issues. This situation has caused many African women to face several reproductive health problems including, but not limited to, unwanted pregnancies and STDS including HIV/AIDS, as well as sexual and domestic violence. McGeary (2001), for example, noted,

Wives, girlfriends, and even prostitutes in sub-Saharan Africa cannot easily say no to sex on a man's terms. It matters little what comes to play, whether it is culture or tradition or the pathology of violence or issues of male identity or the subservient status of women. (p. 42)

This study associates the discrepancy with the reproductive health programs' failure to set appropriate communication objectives to address the real issues affecting people's decision-making power. The study examines the communication strategies used in these programs, changing the overall objective from merely increasing awareness and hoping for behavior change to focusing more on increasing understanding and relationship building with their intended audiences as a way of embracing behavior change achievers encouraging maintenance of new behaviors. The study focuses on rural women because they suffer the most from the consequences of unintended pregnancies. Due to their social status and social-cultural practices that specifically affect women such as female genital mutilation and use of vaginal drying agents, most of them have been victims of several reproductive health infections including HIV. Schoepf (1997), for example, noted that trauma-induced tears in the vaginal skin (mucosa) allow HIV to enter, thus putting women in a more vulnerable situation.

The study also takes into account the role of men in reproductive health since the male sexual partner also plays an important role in reproductive decision making. With the advent of HIV/AIDS and other sexually transmitted infections (STIs), there is a need to promote equal participation of women and men in responsible sexual and reproductive behavior. This study draws its theoretical framework from Grunig's model of excellence in communication (Dozier, Grunig, \& Grunig, 1995; Grunig \& Dozier, 1992), which is based on the idea of strategic communication. The model emphasizes symmetrical two-way communication with the goal of creating an understanding and good relationship between programs and their audiences.

\section{The STD and HIV/AIDS Situation in Kenya}

Reproductive health problems have been on the increase throughout sub-Saharan Africa. At the Eleventh International AIDS conference in Africa held in September 1999, the United Nations Program on AIDS (UNAIDS) pointed out that sub- Saharan Africa is home to 25 million of the 36 million people living with HIV/AIDS, or roughly $70 \%$ of the global total (Mutume, 2001). The numbers are increasing rapidly. In 2000 alone, 3.8 million people were infected in Africa (McGeary, 2001), and in Kenya the director of the National Council for Population and Development (NCPD) 
indicated that some 2 million Kenyans are HIV positive, including about 100,000 children (East African Standard, 2000). A World Bank official who attended the 1998 National AIDS conference in Kenya also pointed out that $12 \%$ of all productive Kenyan adults have AIDS, and 60 Kenyans contract the precursor HIV virus every day (Daily Nation, 1998). The mayor of Nairobi also indicated that one in five people in Nairobi is HIV positive (Daily Nation, 2001).

The rate of infertility due to infection from STIs and other reproductive tract infections in Kenya is also alarming, especially among women of reproductive age and rural women who rarely or never seek medical care. Rogo (1993) noted that between 8,000 and 16,000 Kenyan women become infertile annually because of reproductive tract infections (RTIs) that go untreated. These figures are in line with World Health Organization (WHO) data that indicate that everyday more than one million people are infected with an STI-an estimate of 333 million cases worldwide each year (Family Care International [FCI], 1999). The RTI problems in Kenya, like in other developing countries, have been ignored because of the widespread belief that they are not serious, do not kill, and are too complicated and expensive to control. They also are ignored because of the deeply held attitudes that make them taboo subjects among women and men of all levels of society. Germain (1992) points out that this "culture of silence" prevents changes in long-standing behaviors related to sexuality and gender and that it has inhibited the development of effective information and service.

Among the factors responsible for the increase in reproductive health problems are the deterioration of the country's economy, which has directly affected the health facilities and the quality of health care and the erosion of social-cultural values that previously guided communities' norms. Hartmann (1995) points out that many women and girls in resource-poor settings are at risk of serious infection because they lack access to necessary information and education materials as well as health services. Bauni and Jarabi (2000) also noted that many people continue to believe that directing reproductive health initiatives to adolescents sanctions nontraditional sexual behavior. In Kenya, it is illegal to provide reproductive health services such as contraceptives-including condoms-to adolescents, and the family planning programs in particular are not designed to provide service to unmarried women (Kumah, Odallo, \& Muturi, 1992; Muturi, 1996). The government policy declares that contraceptives should not be made available to young, unmarried people and that other forms of family life education must not be provided in Kenyan schools. This part of the policy is an impediment in HIV/AIDS prevention especially among adolescents. Men and women also refrain from using conventional STI programs because of social censure, financial costs, and other personal inhibitions.

\section{The Role of Communication Programs}

Communication in reproductive health provides knowledge where ignorance and myth prevail. When focusing on reproductive health activities, communication programs attempt to promote proper reproductive behavior and prevent people from contracting STIs, including HIV/AIDS, one of the leading causes of death in Africa today. Communication empowers people by providing them with knowledge and understanding about specific health problems and interventions. Providers also need to know about the various health issues to be able to communicate effectively to their potential clients. This role of communication in reproductive health programs was highlighted in the 1994 Cairo Program of Action that emphasized the need for a multimedia communication approach in reproductive health communication.

For the last decade, much effort has been put into Information, Education and Communication (IEC) programs globally for awareness campaigns that aim at changing people's attitudes and behavior or practices. Common strategies used in reproductive health communication in the world include a variety of approaches: the mass media communication approach that uses a wide variety of mass media channels for awareness building; the social marketing approach that promotes 
the use of condoms and other contraceptives at a minimal cost in an effort to change the behavior of individuals who are impeded by inertia or other resistances; and the enter-educate approach that uses entertainment to spread social messages, reach people, and influence their attitudes and behavior (Piotrow et al., 1997; Rogers, 1995; United Nations Population Fund (UNFPA), 1995). In Kenya, a wide array of mass media initiatives have been set up to inform people about various reproductive health issues including family planning and the advantages of fertility regulation, to keep them abreast of existing methods, and to motivate them to use family planning (Westoff \& Rodriguez, 1995). Similar approaches emphasizing awareness and behavior change are used in the prevention of STIs, including HIV/AIDS.

Unfortunately, the communication approaches used have not proven effective enough to bring about change in behavior. These approaches have been criticized for being one-way communication with an audience at the receiving end, and for not being audience centered. This is particularly the case in Africa where social, cultural, and economic factors mitigate the adoption of healthy reproductive behavior and practices. Most women in many parts of the world suffer from STDs and other RTIs mainly because they do not know about them. When they do know about these diseases, their knowledge is filtered through prejudgments and attitudes that tend to purvey myth and other cultural beliefs and values that impede healthy behavior and practices (Ferguson, 1991; Jagdeo, 1996; Johns Hopkins University [JHU], 1992). Reproductive health programs, however, have not focused on these factors but continue to disseminate messages through the media with the objective of closing the Knowledge, attitude, and practice (KAP) gap or satisfying the unmet need.

\section{Development Communication}

When communication is used for the purpose of development it is termed development communication (Berrigan, 1977) or development support communication (Ascroft, 1985). As noted by Melkote and Steeves (2001), development communication reflects varied underlying views about communication, development, and empowerment. These views are split between "those who view communication as an organizational delivery system and those who view it more broadly, as inseparable from culture and all facets of social change" (p. 37). Communication for development is used most often for persuasion and marketing purposes mainly to sell ideas and associated technologies and to the intended public. For example in the 1960s and 1970s communication was used effectively in the promotion of the family planning idea and modern contraceptives in the developing countries (Rogers, 1995), but today it is used more to persuade aware individuals to adopt the methods and close the KAP gap and increase use of contraceptives. In health, communication is used to inform, educate, and persuade behavior change while promoting healthy behaviors and lifestyles as in the case of HIV/AIDS.

Although the discipline of development communication has existed for several decades, it was not until the early 1960s that the general public recognized its importance for social-cultural, economic, and political development. It is only recently that the role of development communication has been recognized in health and human development. As health communicators continue to apply various communication models developed in other fields, they have benefited from some of those created and used in development communication.

Some of the earliest communication models conceptualized the impact of the mass media on individuals as direct, powerful, and uniform. Models such as Berlo's source, message, channel, and receiver (SMCR) and Rogers' "Diffusion of Innovation" viewed the communication flow as a simple, mechanistic process of message transmission from source to receivers through certain media channels. The models assumed that communicating to or informing the elite, the well-to-do, the articulate, and the educated was all the impetus needed to ensure communication effectiveness (Masilela, 1994; Melkote, 1991; Moemeka, 1994). The assumption was that the inevitable benefits 
deriving from the responses of these highly placed community members would trickle down to the masses. This, however, did not happen. As a result, a new approach emerged in the 1970sparticipatory communication - which is used today in several fields of development.

Participatory communication, as an approach in development communication, has been identified as essential to the "basic needs" approach to development, and participatory methodologies have been applied in development programs (United Nations Development Program (UNDP), 1993). This change of paradigm from a one-way, trickle down communication to a participatory communication approach was reinforced by, among others, the United Nations Food and Agricultural Organization (FAO) that urged the integration of multimedia with interpersonal communication approaches and strongly recommended participatory communication that involved the target audiences of development projects. It was also understood that participatory decision making required knowledge sharing between the "experts" and the "beneficiaries" of development projects (Chambers, 1983; Melkote, 1999). Researchers and program planners have interpreted the goal of the participatory approach as the involvement of people in the problem definition, data collection, decision-making, and implementation processes.

More recently, emphasis has been on participatory communication in health communication where stakeholders are involved in the communication related to prevention and care, ensuring that they have access to clear and accurate information to guide them to make informed decisions. With new communication technology-Internet, e-mail access, and other digital communicationcommunication between providers and care seekers becomes much easier and convenient, thus enabling more people to participate in decisions related to their own health care.

The participatory communication approach in health is a big leap from the traditional health communication that aimed at reaching a wide audience through health campaigns. This leap, however, does not overrule the traditional approach as some health programs have applied efforts to educate people at the clinics, through information campaigns and the media, about various services and the recommended reproductive health behavior (Rogers, 1995; Weijts, 1994). The private nature of the reproductive health issue, however, coupled with the fact that individual women may not make their own decisions without involving other family members, sets limits to the extent of women's participation in some communities.

Today, in addition to a call for a participatory communication approach in health, there has been another call for strategic communication to replace the one-way transmissional, doctor-patient approach. Piotrow and Kincaid (2001) define strategic communication as "based on a combination of facts, ideas, and theories integrated by a visionary design to achieve verifiable objectives by effecting the most likely sources and barriers to behavioral change with the active participation of stakeholders and beneficiaries" (p. 251). Writing about lessons learned from health communication, colleagues from Johns Hopkins write, Today is an era of strategic behavior change communication, which is founded on behavioral science models for individuals, communities and organizations that emphasize the need to influence social norms and policy environments so as to facilitate and empower the iterative and dynamic process of both individual and social change (Piotrow, Rimon, Merritt, \& Saffitz, 2003, p. 2). They note that this era has evolved from the clinic era that focused on health centers, the field era whose focus was on outreach, and the social marketing era that stressed effective delivery of services. Strategic communication complements the participatory approach in ensuring the effectiveness of communication through dialogues and increased understanding of communicated messages.

\section{Excellence in Communication Model}

Grunig's theory of excellence in communication, developed in public relations, provides the elements of a strategic communication model for a successful communication program. Grunig's excellence in 
communication theory is based on the idea of strategic planning and communication management for the success of communication programs to reach the intended audience (Grunig, 1990, 1995, 2001; Grunig \& Dozier, 1992). Communication in this theory is practiced strategically where programs are developed to communicate with specific audiences. Strategic constituents represent groups that are deemed to be most critical to the program, and effort is put toward strategic communication and relationship building with them.

Strategic planning of communication activities is emphasized in the excellence theory. Grunig argues that most programs do not plan their communication activities, and in the end they waste a lot of money. Agunga (1997) observed this problem in development communication programs. He pointed out that most development programs fail because they do not pay attention to communication concerns and, hence, they do not plan their communication activities properly. What appears to be problematic is lack of attention to communication concerns and, where communication exists, it is narrowly perceived as a "mass media technologies" problem. Strategic communication involves audience segmentation. In Grunig's (2001) own words, "there is seldom any need to communicate to the mass audiences" (p. 19). He emphasized using the logic of situational theory of publics to identify potential publics that share problems and to organize those publics using interpersonal communication, given that members of these disempowered publics seldom pay attention to mass-mediated messages. Furthermore, objectives of strategic communication should focus on attitude change and awareness. Literature indicates that communication programs seldom change behavior in the short term, although they may do so over a long period of time (Cutlip, Center, \& Broom, 2000; Grunig, 1990; Grunig \& Dozier, 1992). Boyer (1997) also indicates that "useful considerations to keep in mind would include knowing the attitudes of the audience at the start of the project; their stage of understanding; the appropriate ways of reaching them, including consideration of culture; and other matters that are competing for their attention" (p. 489). Such factors are necessary in the systematic planning and implementation of an effective communication program ensuring that the audience has access to and understands the messages or information provided to them.

Research is used to identify the appropriate strategies for each segment of the population. Appropriate strategies may include various public health interventions, behavior change communication, marketing and mobilization strategies, counseling, or using different tactics (Piotrow \& Kincaid, 2001). The emphasis of Grunig's theory is the ideal two-way symmetrical communication through dialogue to develop mutual understanding between organizations and their audiences. This element of the model brings about understanding and relationship building between programs and their audiences. It makes the model more applicable in reproductive health communication programs and other development organizations where understanding is needed for any change in behavior or practices to occur.

\section{Research Questions}

Effective communication attempts to understand the audience and help it to increase comprehension of the messages being communicated. This necessitates identifying what the audience knows and why they behave as they do. This paper is based on three broad research questions:

(a) What do people know about STDs including HIV/AIDS?

(b) What social-cultural factors put them at risk of HIV/AIDS infection and how much do they perceive themselves at risk?

(c) What influences their decision to or not to protect themselves from contracting STDs including HIV/AIDS? 


\section{Methodology}

This qualitative study sought to explain and understand the reasons behind the lack of change in reproductive health behavior and practices among rural populations in Kenya as indicated in the existing KAP gap (Gule, 1994; NCPD, 1998; Westoff \& Rodriguez, 1995). As Wimmer and Dominic (1991) stated, "Qualitative research attempts to produce a unique explanation about a given situation or individual where the researcher examines believing that reality is holistic and cannot be subdivided" (p. 139). Christians and Carey (1989) also contend that qualitative studies start from the assumption that in studying humans we are examining a creative process whereby people produce and maintain forms of life and society and systems of meaning and value. They emphasize that, "Humans live by interpretation. They do not merely react or respond but rather live by interpreting experience through the agency of culture" (p. 358). Scholars (e.g., Collins, 1990, and Madriz, 2001) also have indicated the importance of qualitative methodologies to study a less literate, lower socioeconomic class of women because this gives them an opportunity for self-expression and empowerment.

Data for this study were specifically gathered for 5 months in the Murang'a District, Kenya, which is predominantly occupied by people of the Kikuyu ethnic group (20\% of the Kenyan population). The Kandara division, one of the six divisions of the Murang'a district, was conveniently selected, and two rural communities within the division were selected for the study. Due to the monotony of the responses, the author conveniently selected one suburban community in Thika for comparison purposes. The town is located outside but adjacent to the Kandara division and therefore it is a central place for health care, market, administration, and other needs that people have.

The major tools for data collection included focus group discussions and in-depth interviews to gather information from the respondents regarding their reproductive health situation and related social-cultural factors. Six focus groups, two from each community, were conducted. Each focus group had 6 to 8 respondents and they were conducted separately among men and women. Due to the sensitivity of the topic, it was necessary to have separate groups for men and women to allow them to openly discuss the topic with other participants who were carefully selected and matched according to their age, education level, and other demographics. In total, 40 people (22 women and 18 men) participated in the focus groups. The author conducted focus groups to become familiar with the respondents and gather general information on their knowledge, beliefs, attitudes, values, and norms regarding reproductive health and family planning practices, understanding of HIV/AIDS and other STDs, and on factors putting people in their communities at risk of infection.

Focus group participants were able to discuss various reproductive health related issues with their peers, including those that some of them did not understand. For example, a 27-year-old woman who indicated never having seen a condom was happy to learn from others how it looks and how it feels when the sexual partner has it on. At the end of the discussions, most women indicated having learned from these discussions and wondered if they could be done more often. The discussions were tape-recorded on audiocassettes with the respondents' permission and the information gathered formed the basis for discussion in the subsequent one-on-one in-depth interviews.

In-depth interviews were conducted to gather the more personal information that respondents could not talk about openly at the focus groups. The goal of conducting one-on-one interviews was to allow respondents to explore in detail their sexual behavior and reproductive health behavior and practices, their perceived risks of infection, as well as their concerns and obstacles that they face in seeking information, education, or services. Out of 40 focus group participants, 28 were able to participate in the interviews and 12 more who had not participated in the focus groups were purposively selected from their respective communities.

During interviews, women in particular were much more willing to discuss with the researcher their family planning experience as well as their fears and vulnerability in HIV/AIDS infection. Men, on the other hand, talked more about their sexual practices, STDs, and how they deal with their 
STDs. Simple observations and note-taking methodologies also were used throughout the study to supplement the two main data collection techniques.

Data for this study were analyzed qualitatively using descriptive and interpretative techniques. The kind of description required to give rigor to qualitative analysis is referred to as thick description. Denzin (1989) states that thick description "presents detail, context, emotion, and the webs of social relationships that join persons to one another. It inserts history into experience” (p. 83). Interpretation by definition involves going beyond the descriptive data. Patton (1990) contends that in terms of qualitative analysis, interpretation means attaching significance to what was found, offering explanations, drawing conclusions, extrapolating lessons, attaching meaning, imposing order, dealing with rival explanations, and confirming cases and data irregularities as part of testing the viability of an interpretation.

\section{Findings}

This study aimed at examining the gap between awareness of reproductive health and change of behaviors and practices. Previous studies had indicated that the presence of STDs within a population increases susceptibility to and the chances of infection with HIV. Considering this alarming information, which is corroborated by many surveys, media reports, and studies conducted in different parts of Kenya, respondents were asked how serious the situation was in their communities. The majority of the participants felt that STDs were prevalent but not as serious as AIDS because it is common knowledge that there is no cure for AIDS and many people are dying from it. Some of the commonly known STDs that were cited were gonorrhea, syphilis, and herpes, but they were not considered serious and therefore people learn to live with them, sometimes without seeking treatment. A male participant in one rural focus group stated,

I can tell the same day if I have been infected and if I go to see the doctor or an herbalist within three days I can be cured completely. If I avoid "seeing" my wife during those days, she will never know that I went somewhere else. That's what most men do if they don't want to make their wives sick.

Other participants in the same group pointed out that they take medication that cures their wives through them. Clarifying the point, another male participant said, "If I take the tablet, it goes to her through me, so we have to keep doing it [having sex] during that time so we can both be cured." Most male participants indicated that STDs are just like a common cold; that is, most people do not seek medical treatment from a professional doctor. For example, one 38-year-old suburban male participant, a primary school teacher who was among the first male respondents that I interviewed, indicated, I have been infected with STDs more than 50 times, but I took medicine before they get serious. Sometimes I went to the herbalist if I did not have enough money to see a doctor. I contracted them from the schoolgirls that I taught whom I thought were innocent, but they weren't. None of them is good. They may seem young and beautiful, but they are deadly. These days I try to avoid them.

All the study participants also knew about AIDS even if specific knowledge of the diseases remained limited especially among rural respondents. For example, some of them believed that one could get AIDS through insect bites, used clothing, or shared cups, spoons, and plates, and they thought that this was how and why AIDS was spreading widely in the communities. Others did not believe they could get it from family members or close friends.

In spite of this increased awareness about STIs and the risk of contracting HIV/AIDS, the majority of rural respondents reported that they continued to engage in high-risk sexual behaviors. This study found practically no behavior change-a situation that most respondents attributed to the 
pervasiveness of social and cultural customs, especially those that entitle men to have multiple sexual partners simultaneously. Suburban men, on the other hand, although they indicated no change of behavior, also expressed the fact that they use protection most of the time when they are with nonregular partners or in sexual relations with women other than their wives.

The practice of multiple partners is detrimental to the reproductive health of those involved. Although common in most parts of the world, the practice is unique in the African societies due to the fact that over the years it has been accepted as a norm. Polygamy, for instance, was and still is commonly acceptable in many Kenyan communities in spite of the HIV/AIDS epidemic. The few women who oppose it do so mainly for economic reasons. This is particularly true when the polygamous man cannot support all his wives financially or when his property is too small to be profitably divided amongst all his sons. One of the common arguments mentioned by group participants was that if the man was supporting the family, there was nothing else they want from him. This means he gets license to keep extramarital relations that often lead to pregnancy or STDs.

A common statement in all the focus groups was that unlike machetes, men are not one-sided; that is, they cannot stay with one woman, and this includes young men who are not yet married. They believer, therefore, that they should have multiple "sides," should one side become blunt or useless. This value is held among younger and older men, yet there is no way of knowing whether the new wife or partner has been infected with an STD or is HIV positive. In case she is, it is a sure way of infecting not only the new husband, but also other wives or sexual partners in and out of wedlock. As my informants indicated, the "don't care" attitude among both men and women coupled with deteriorating moral values has caused the persistence of many STIs in the communities.

Questioning spouses' sexual behavior or asking them to use preventive measures such as condoms often leads to physical, verbal, or other forms of domestic violence, and most women prefer to go to the hospitals without letting anyone know in order to avoid confronting their spouse. In one of the rural focus groups, men indicated clearly that they would not admit being responsible for spreading diseases if confronted by their wives. A middle-aged participant who was very emphatic argued,

I cannot admit it because that would mean I'm guilty and it might cause more problems. Instead, I would open my eyes wide and tell her point blank that she is promiscuous and she should tell me where she got the disease from or else I tell her parents and everybody else. When it comes to that, no woman will want the case to go any further and she will settle things down unless she is asking for trouble.

To avoid such trouble, some women prefer to seek treatment quietly once they realize they have been infected. Women who lack resources to seek medical care live with the infections hoping that the situation will somehow get better.

There are many others, however, who prefer not to seek medical attention due to the attitudes of the health professionals. Focus group participants indicated that nurses portray negative attitudes toward their patients especially if they seek treatment for STIs, thus discouraging the women from visiting the clinics or going for follow-up visits. One of the rural female respondents, about 32 years old, who had such an experience, for instance, noted during an interview, They treat everyone who comes to the clinic with a VD [venereal disease] as if she is a prostitute. I don't want them to think I am a prostitute because I am not. I don't think I can go back there.

Some male respondents also indicated bad experiences when they sought treatment for STIs, indicating preference for private clinics because some health personnel in the public clinics will require them to bring along their sexual partners in order for both to get treatment. Focus groups participants noted that this is mainly a requirement from the female nurses, which made them unpopular particularly among their male clients. A rural respondent, a 37-year-old married man who 
had encountered the problem while seeking treatment from a certain health center, which he refused to name, indicated,

If I go to a clinic and find a young female nurse, I will just go back home. I might try again until I find a male worker. Those young women are rude and they always try to embarrass us telling us to bring our women with us if we want to be treated. What can you do if you got it from someone's wife or girlfriend, you can't bring her with you? For me, I would rather go to an herbalist or to a private clinic, you know, the Indians' clinics. There you get what you want and go home with no questions because they know what the problem is and what we want when we go to them.

This practice was actually observed in this study when I visited a private clinic in Thika town. There was a long line of men and women waiting and because it was a small two-room clinic, we could hear the communication between health personnel and their patients. When it was his turn, one male patient entered and after saying hello to him, the health worker said in Swahili,

Ni ile Ugonjwa yetu? Usinjali, hiyo ni rahisi, kunya hizi kama kawaida mpaka ziishe na urudi tena ukiipata tena. Enda ulipe pale. (Is it our disease? Don't worry, that's easy. Take these as usual until they are finished and come back when you get it again. Go and pay over there.)

It was clear in this study that the health care worker did not take time to explain to his patient about the need to protect himself, let alone ask him to inform his partner that she needed to seek medical treatment too. Of concern was also the confidentiality issue that is neither addressed by the doctor nor by other clinic personnel. As such it has discouraged many people from seeking services or even testing for STIs including HIV. This by itself has in many ways contributed to the ever-spreading epidemic in the country.

The problem was not faced only by rural men, as urban respondents recounted various incidences where they felt that the health personnel were rude and insensitive to their needs. In general my respondents indicated that the attitudes of health professionals affect their need to seek reproductive health care, attending the clinics only when they absolutely have to do so.

Similar problems with health care professionals exist in other parts of Africa, thus widening the gap between them and care seekers as in the case of family planning. For instance, focus group research in Egypt and Imo State Nigeria found that certain health facilities were eschewed because of the rude and uncaring attitudes of health care personnel (Attah, 1986; Piotrow, Treiman, Rimon, Yun, \& Lozare, 1994). Training health care providers in interpersonal communication skills has been recommended as a strategy for rectifying this situation.

\section{The Risk of HIV/AIDS}

If focus groups participants did not think STDs were a real concern, they all seemed to agree that HIV/AIDS is a very serious health problem in both urban and rural areas. The consensus in the group discussions was that although STDs are common in the communities, they are treatable, whereas AIDS has no cure. They supported their fears by providing several examples of people who were known to have died from AIDS or were suspected to be HIV positive. The rural focus group gave the example of a local family that had lost five members, all well-educated and prominent young men and women, whose ailing parents were left in charge of the grandchildren.

About half of the participants, both men and women, felt that they were at risk of contracting STDs and more particularly AIDS. Those who felt at risk cited several ways of getting infected, including "illicit sex," careless unprotected sexual behavior of their partners, and untrustworthy 
partners who engage in multiple sexual relationships. This sexual network, however, is not acceptable if initiated by women. Any woman who was seen with or suspected of having more than one partner was blamed for spreading the disease. One respondent, for example, talked about a local woman who was labeled with having AIDS just because she worked in a bar and was seen with various men. She noted,

Even school children know her as AIDS. When they see her they run away screaming, "AIDS! AIDS! AIDS!" and they run away. They think she is spreading it to everyone in this area and they run away so they don't get it from her.

Children and many others get infected from other family members by sharing vital items such as needles, pins, razor blades and so on, that can spread the HIV virus. The problem is intensified by the fact that Kikuyu communities are by and large hospitable, which means that family members also share items with strangers who come and stay with the family, as frequently happens. A 39-year-old woman noted how she had been sharing personal items with friends and relatives who stay with her and her children. Believing that this would not cause any infections because those who come to visit are usually people she knows, she noted,

It depends on who your friends are. If they are immoral people, they can make you sick. Last month the church ministers came to my house and we stayed until late at night, and I told them there was no need to go home that late. In the morning, they used our toothbrushes and I had no problem with that. I just washed them with soap and nobody has been sick and if anyone was sick, I am sure God will protect us.

Similar statements were made indicating lack of knowledge and understanding about other means through which the virus can be spread among family members and individuals who do not engage in sexual relations. Health programs have not addressed this issue adequately if at all, certainly not in the Kenyan rural communities where people thirst for more information on HIV/AIDS prevention methods. The fact that people do not talk about sexuality issues especially among family members, coupled with the stigma attached to AIDS, makes it more difficult to know who is infected and who is not until it is too late. Women also felt that they were at greater risk of contracting the infections from their family members because they take care of them, including when they are sick or debilitated by the disease.

\section{Lack of Communication}

Lack of communication among sexual partners, especially when one of them is infected with an STD or other infection, is common, and the situation puts many people at risk of contracting infections. Some of the women who had been infected pointed out that their husbands never talked to them about the infection and that they never advised their wives to seek treatment. They made comments such as,

The worst case is when your partner lives away from home and when he comes on his regular weekends, they are either not aware of the infection or they simply cannot abstain or use a condom for fear of suspicion by their wife. He will infect you and before you know it he will be gone again, or maybe you will feel it when it is time for him to come back again. You can never ask him because he will deny it and you will be the one to blame. 
Most rural women are left at home to take care of the households while their husbands work in the city. Although some men return home on weekends, at the end of month, or during the holidays, others come back home less frequently or they do not come back at all. It is common for these men to seek other sexual partners in the absence of their wives. Their wives, on the other hand, sometimes become victims of crime, including rape, because it is common knowledge in the communities whether the husbands are at home, and some individuals take advantage of the absence of a male partner to engage in out-of-wedlock consensual sexual activities.

When a man discovers he is infected with an STD, ideally he should seek medical attention and advise his sexual partner to do the same. Respondents indicated, however, that this does not happen in most cases. "Some men seek treatment immediately after they discover they are infected and abstain from sexual intercourse for a week or so while taking the medication to avoid infecting their partners, that is what everybody should do, but they don't," one rural woman in the focus group pointed out. Another woman in the same group agreed: "Good men will tell their partners as soon as they discover they are sick so that both of them can seek treatment, but it is a very rare thing."

By not telling women to seek treatment before the infection becomes serious, men contribute to the deteriorating reproductive health of the women, which can sometimes lead to infertility. Schoepf (1997) noted that because signs are often subtle and many men do not notify their partners, women may not know when they are infected, and even when they suspect an infection, shame may prevent them from seeking treatment. Women who had been infected previously agreed that if they had known about the infection sooner, they would have sought treatment before it became serious.

A study conducted by Bauni and Jarabi (2000) identified several reasons why Kenyan couples do not communicate about family planning or STDs. These included cultural beliefs, ignorance, religious beliefs, and men's obstinacy, all of which influenced their decision not to discuss reproductive health issues with their spouses or not to use condoms even when they were aware that they would become infected or infect others. In this study, the education of the wives and the socioeconomic status of the family were related to their level of participation in spousal communication. When the wife had a few years of schooling, a career, or some income, more communication took place. Unfortunately, the majority of rural women have very little or no education. This, coupled with the patriarchal power extant in families and communities, makes it impossible for them to communicate with their spouses regarding sensitive issues such as family planning and transmission of STDs.

Lack of communication about HIV/AIDS also exists between health care providers and their clients in other parts of Africa. As McGeary pointed out (2001), doctors do not say anything even to close relatives on the basis that such information is confidential. Unwillingness to be tested is common among most people in sub-Saharan Africa because nobody wants to know that they will be dying soon, especially if it is from AIDS. In Southern Africa, McGeary (2001) observed,

Rare is the man who even knows his HIV status: males widely refuse testing even when they fall ill. And many men who suspect they are HIV positive embrace a flawed logic: if I'm already infected, I can't get it again. But women are the ones who progress to full blown AIDS first and die fastest, and the underlying cause is not just sex but power. (p. 42)

When the health professional does not intervene, patients, including pregnant women, do not tell anyone, not even their spouses or other sexual partners, that they are infected. The fact that doctors do not address the problem appropriately either could be associated with the confidentiality issues involved or with ignorance as to how to deal with the problem. It also could be associated with the stigma associated with AIDS commonly being associated with promiscuity; they do not communicate with the patients as a way of allowing them (patients) to save face. This latter explanation was indicated by a medical technologist who also owns a health clinic and therefore works as a health care 
provider. In a conversation regarding how to approach people with HIV-positive results, he pointed how difficult it is especially when the health professional knows the patient well. He associated this challenge with the lack of training in both communication and counseling skills. Other health professionals fail to intervene because of the way some patients react when they hear their HIV test results. For example, the study found that there are instances when infected people, out of bitterness, deliberately spread the virus to others by engaging in unprotected sexual activities or rupture or slip off their condoms.

\section{Rupturing Condoms}

Previous studies have indicated that slipping or rupturing condoms in the process of sexual intercourse is common among African men. In a study conducted by Steiner, Piedrahita, Joanis, Glover, and Spruyt (1994) on condom breakage and slippage among men of reproductive age, Kenya had the highest rate $(13.3 \%)$ compared with other countries such as Sri Lanka and the United States (3.6\%). The study identified four types of user behavior that may cause condoms to break: an incorrect method of putting on a condom, the use of oil-based lubricants, the reuse of condoms, and the duration and intensity of coitus.

In our discussions on condom use, rural men indicated that condoms were unreliable for protection of either pregnancy or STDs because they often rupture, or "bust," as one participant put it. When asked why they thought condoms bust, some men indicated that it was probably because they usually receive expired condoms from the distributing agencies. Others in the group thought that condoms rupture because of the vigor of the sexual activity, while a few men thought that the women were too dry to keep the condom moist. Urban men, on the other hand, associated condom breakage to size. Condom distributors have only one size that supposedly fits all men. The group participants tended to agree that condoms are tight, which makes them uncomfortable-a good reason to take them off particularly when they are about to ejaculate. Both groups, however, preferred dry sex because they thought it was more pleasurable.

As literature indicates, African men generally prefer dry sex, and women go to extremes to make this happen. For example, men consider foreplay a waste of time probably because sexual intercourse among the Kikuyu is culturally for procreation, not recreation. Such practices in which the condom is deliberately broken or slipped off or conditions such as vaginal dryness or adding lubricants that will cause the condom to break, not only increase the risk of reproductive health infections but also constantly put women at risk of contracting HIV/AIDS and causing unwanted pregnancies. Steiner and colleagues (1994) pointed out that as recently as in the mid-1990s, the scientific literature and the popular press asserted that condoms broke less than $1 \%$ of the time and slipping off occurred between $0.8 \%$ and $6.4 \%$ of the time. As indicated by the example above, one of the reasons for the high percentage is improper condom use, which leads to serious reproductive health problems for women and men who infect one another.

\section{Youth at Risk}

Young people are especially at risk for HIV infection due to their age, biological and emotional development, and financial dependence. This makes them have little or no decision-making power when it comes to when and with whom to engage in sexual relationships. Young people who still need to have children or single men and women who are looking for marriage partners are also at risk. Their situation puts them at a higher risk because they are not obligated to have monogamous relationships or protect their partners. One of my respondents, a 23-year-old hairdresser in Thika town who was still grieving for her cousin who had died from AIDS said, "It is very hard for young women because we need husbands but we can't tell who is sick or who is not." 
Use of protective measures such as condoms for STD or HIV prevention also does not occur, especially when young people have (or intend to have) long-term relationships. For instance, male respondents noted during focus group discussions that they rarely use condoms even with new partners. Echoing the responses of others in the group, a 25-year-old male noted later in an interview:

We don't go looking at young women and wondering who has AIDS and who doesn't. We look for beautiful women and try our luck. You can never know when you will be lucky because it is hard to tell with women. Sometimes they want to but they don't say it. So when they want, maybe you don't even know where to get a condom from, what do you do? You just do it and hope that she won't make you sick or get pregnant.

Lack of condom use among the younger generation has put them at greater risk of HIV infection. Unfortunately, most sexually active young people do not believe themselves to be at risk and most HIV-positive young people do not know they are infected with the virus. A 23-year-old suburban male, when asked if he has been tested, responded,

Why should I get tested if I know myself? I don't feel sick and I haven't gone to the doctor for many years. I am sure I am okay, but if I get sick and I don't get well, I might go to the doctor to get checked. I can't go now. What if they say I have it, what would I do, die?

This attitude toward getting tested for HIV and the failure to do so has caused many youth to continue living with HIV/AIDS and unknowingly to spread it to others. Other factors that have put them at risk are closely linked to their economic status because most of them engage in sexual practices for economic reasons. Due to this financial dependency, some HIV-positive persons have targeted them, deliberately infecting them with the virus. In almost all the focus groups, participants also indicated that rich men who have tested positive often offer money to young, beautiful women to have unprotected sexual intercourse with them. After the act, the women are offered money and they are told to buy a coffin for themselves since they will need one sooner or later.

The fear attached to HIV/AIDS may be partly related to this practice. Several HIV prevention media campaigns focus on engendering fear of HIV without also specifying ways to address this fear appropriately (Yun, Govender, \& Mody, 2001). This has contributed greatly toward the stigma attached to HIV/AIDS and has caused anger and bitterness among those who become infected. McGeary (2001) indicated that those infected argue that once they are infected they cannot get infected again, so they do not need to use protection when having sexual intercourse. If their partners insist on using protection, they deliberately tear or slip off the condom during sexual intercourse. Some of the female informants reported that they had witnessed this kind of behavior among men and that it increases not only the chances for unplanned pregnancy but also the risk of HIV infection.

Other factors mentioned as causing a rapid increase in HIV/AIDS in the rural communities include alcoholism and crime, particularly rape. Alcoholism was also associated with AIDS infection in both rural and suburban areas. A 37-year-old woman whose husband is a heavy drinker, for example, noted in an interview that she is constantly worried about her husband because he drinks and does not come home at least twice every week. The husband, who was also interviewed on a separate occasion, also confirmed that he does not go home after drinking citing the risk of driving while drunk. Instead, he noted, "I prefer to spend the night in the club and go home in the morning when sober. What would I be doing at home on a Saturday night apart from sleeping?" Rural communities are particularly affected because they offer few other entertainment alternatives. A middle-aged rural woman who declined to give her age indicated, 
Men lose control by drinking too much and can sleep with any woman they come across in that state of drunkenness; they indulge in sexual activities especially with prostitutes who spend time in bars.

When the issue of alcoholism and sexuality came up in the men's focus groups, men admitted that once they drink, they lose control of themselves and may be tempted to engage in sexual activities, especially with prostitutes. By the time they realize what has happened, it may be too late. One male respondent pointed out, "There is usually no time to think of protection. Besides, where would one get the 'gumboots' [condoms] for protection at night?" Another man added, "At that time one is rushing to get home before dawn, before everybody wakes up in the morning." Women in one focus group discussion also pointed out another practice associated with alcoholism among men: They spend days in the cities at the end of every month when they get their salaries or when they receive payment from their cash crops. Some of them do not come home until the money is gone. Rather, they stay and spend the money with prostitutes. That kind of behavior often leads to physical violence, especially when the wife asks for financial support for the children and men sometimes bring infections home to their wives after contracting them from the prostitutes.

Crime also was mentioned as a major cause of AIDS infection in the communities. Rape particularly was perceived as putting individuals at risk. Urban women especially expressed fear that it was becoming common for women to be raped in broad daylight without anyone reacting. Unfortunately, most Kenyan women do not report rapes or attempted rapes because they fear intimidation either from the police or other official administrators who are supposed to help them deal with the situation. It is only recently that such cases have been taken seriously, mainly as a result of pressure from nongovernmental organizations (NGOs) like the Foundation for Women in Education (FAWE) and other lobby groups that have constantly pressured the government to revise its policy to take issues of gender, violence, and HIV/AIDS into consideration. More recently, a family court also has been established to deal with such cases. Additional effort is required, however, from the government, health organizations, and NGOs in educating and empowering the general public and protecting women against such criminal activities. Such effort will contribute to the participatory effort in fighting HIV/AIDS in the country.

\section{Concluding Remarks}

Although it is common knowledge that awareness does not necessarily lead to behavior change, lack of understanding of the communicated messages makes it more difficult for this change to occur among the targeted audience regardless of their level of awareness. Understanding, particularly of the facts related to HIV/AIDS infection and prevention, is necessary especially in communities where the majority of the population still has limited knowledge. Communication activities in these communities also should take into consideration the norms, values, beliefs, and other social-cultural factors that are unique in every society. These factors dictate how people perceive the risk of HIV/AIDS and how they deal with it when they are infected or affected by it. They also affect people's reproductive health decision to take protective measures or not, including use of condoms against infection from STIs. These components, however, have not been adequately incorporated in reproductive health communication.

The Excellence in Communication model stresses understanding the audience and building a relationship with them as important components for behavior change. Communication programs based on this model use appropriate research methodologies to understand their audience and design strategies that will increase understanding and build relationships with them. Graeff and colleagues (1993) noted that understanding the audience requires use of relevant information-gathering 
methodologies and may require communicators to enter into a dialogue with the community through use of ongoing systematic research with representatives of the target audience. Participatory communication through two-way symmetric dialogues and between communicators and target audience is necessary in HIV/AIDS communication.

Holding dialogues in the rural communities regarding the epidemic with those most affected would enable them to participate in the development of interventions and communication strategies. This communication approach, however, requires further research on how to involve the people, considering the nature of the problem and the existing gap between them and the health professionals. Further research also is required in determining the best strategies for relationship building particularly between health care providers and their clients, who ideally should join forces in the fight against HIV/AIDS.

\section{Acknowledgments}

Many thanks to the Association of American University Women (AAUW) Educational Foundation and to the University of Iowa's Graduate College for funding this project.

\section{References}

Agunga, R. A. (1997). Developing the third world: A communication approach. New York: Nova Science Publishers.

Ascroft, J. (1985). A Curriculum for Development Support Communication. Prepared for the Universities in Pakistan for a Development Communication Workshop. Addis Ababa, Ethiopia.

Ascroft, J. \& Agunga, R. (1994). Diffusion theory and participatory decision making. In S. A. White, K. S. Nair, and J. Ascroft (Eds.), Participatory communication. Working for change and development. New Delhi: Sage Publications.

Atkin, C. K. \& Meischke, H. W. J. (1989). Family planning communication campaigns in developing countries. In R. E. Rice and C. K. Atkin (Eds.), Public communication campaigns, (2nd ed.) Newbury Park, CA: Sage.

Attah, E. B. (1986, January). Underutilization of public sector health facilities in Imo State, Nigeria. A study with focus groups, PHN Technical Note 86-1, Washington, DC: World Bank.

Bauni, E. K. \& Jarabi, B. O. (2000). Family planning and sexual behavior in the era of HIV/AIDS: The case of Nakuru district, Kenya. Studies in Family Planning, 31(1), 69-80.

Berrigan, F. J. (1977). A manual on mass media in population and development, France: UNESCO.

Boyer, R. (1997). Public relations and communications for non-profit organizations. In C. L. Caywood (Ed.), The handbook of strategic public relations and integrated communications. (pp. 481-498). New York: McGraw-Hill.

Chambers, R. (1983). Rural development: Putting people first, London: Longman. Christians, C. G. \& Carey, J. W. (1989). The logic and aims of qualitative research. In G. H. Stempel and B. H. Westley (Eds.), Research methods in mass communication, (2nd ed.), pp. 354-374. Englewood Cliffs, NJ: Prentice-Hall.

Collins, P. H. (1990). Black feminist thought: Knowledge, consciousness, and the politics of empowerment. New York: Routledge, Chapman \& Hall.

Cutlip, S., Center, A., \& Broom, G. (2000). Effective public relations 8th ed. Englewood Cliffs, NJ: Prentice-Hall.

Denzin, N. K. (1989). Interpretive interactionism. Beverly Hills, CA: Sage.

DiClemente, R. J. (1992). Adolescents and AIDS, a generation in jeopardy, Newbury Park, CA: Sage. 
DiClemente, R. J. \& Peterson, J. L. (1994). Preventing AIDS: Theories and methods of behavioral interventions (pp. 5-24). New York: Plenum Press.

Dixon-Mueller, R. (1994). Women's rights and reproductive choice: Rethinking the connections. In L. A. Mazur (Ed.), Beyond the numbers: A reader on population, consumption, and the environment. Washington, DC: Island Press.

Dozier, D., Grunig, L., \& Grunig, J. (1995). Manager's guide to excellence in public relations and communication management. Mahwah, NJ: Lawrence Erlbaum.

Family Care International (FCI). (1999). Meeting the Cairo challenge. Progress in sexual and reproductive health. New York: Author.

Ferguson, A. (1991). Family planning adoption, change, and discontinuation: A retrospective study from two rural areas of Kenya. Nairobi, GTZ: Family Planning Support Unit, Division of Family Health, Ministry of Health.

Freedman, R. (1975). The high fertility of less developed nations. In D. M. Hear (Ed.), Readings on population. Englewood Cliffs, NJ: Prentice-Hall.

Germain, A. (1992). Reproductive tract infections: Global impact and priorities for women's reproductive health. New York: Plenum.

Graeff, J. A., Elder, J. P., \& Booth, E. M. (1993). Communication for health and behavior change: A developing country perspective. San Francisco: Jossey-Bass.

Grunig, J. E. (1990). Theory and practice of interactive media relations. Public relations quarterly. Fall, $18-23$.

Grunig, J. E. (1995, August 7). A reply: Regan report publisher's reviews of the excellence report show he understands neither PR nor PR research. Regan Report.

Grunig, J. E. (2001). Two-way symmetrical public relations: Past present and future. In R. Heath and G. Vasquez (Eds.), Handbook of public relations. Thousand Oaks, CA: Sage.

Grunig, J. E. \& Dozier, D. M. (1992). Excellence in public relations and communication management. Hillsdale, NJ: Erlbaum Associates. IABC Research Foundation.

Gule, G. (1994, August). A review of family planning in Africa. African Population Paper. No. 2. Nairobi: African Population and Environment Institute.

Hartmann, B. (1995). Reproductive rights and wrongs: The global politics of population control, Boston: South End Press.

International Project Assistance Services (IPAS). (1999). Unsafe abortion, global and regional estimates. [On-line]. Available: http://www. ipas.org

Jagdeo, T. P. (1996). Diffusion of innovative behavior and information, education and communication activities. In United Nations (Ed.), Family planning, health and well-being. New York: United Nations. Johns Hopkins University. (1992). Population reports. Series M, Number 11.

Kim, Y. M., Kols, A., \& Mucheke, S. (1998). Informed choice and decision-making in family planning counseling in Kenya. International Family Planning Perspectives, 24(1), 4-11.

Kumah, O. M., Odallo, D., \& Muturi, N. (1992). Kenya youth IEC needs assessment. Baltimore: $\mathrm{JHU}=$ Population Communication Services (PCS).

Madriz, E. (2001). Focus groups in feminist research. In N. K. Denzin (Ed.), Handbook of qualitative research (2nd ed.), pp. 835-850. Thousand Oaks, CA: Sage.

Masilela, S. (1994). Communication strategies for community participation in the nongovernmental space of development efforts: The case of Kibwezi, Kenya. Unpublished doctoral dissertation, University of Iowa, Ames.

McGeary, J. (2001, February 12). Death stalks a continent. Time Magazine, 36-45.

Melkote, S. (1991). Communication for development in the Third World: Theory and practice. New Delhi, India: Sage. 
Melkote, S. R. (1999). How Should Development Support Communication Address Power and Control Issues in Third World Development? A nomological analysis. Paper presented at the Annual International Association of Education in Journalism and Mass Communication (AEJMC), International Communication Association, New Orleans.

Moemeka, A. A. (1994). Communicating for development: A new pan-disciplinary perspective. New York State University Press. New York.

Mutume, G. (2001, January). African leaders declare war on AIDS. Africa Recovery, A United Nations Publication, 14, 4.

Muturi, N. (1996). Sex education: The appropriate communication strategies for school-age children in the Third World. Unpublished Master's research project, University of Iowa, Iowa City

Muturi, N. (2002). A reproductive health approach to family planning: Toward strategic communication for development in Kenya. PhD Dissertation, University of Iowa, Ann Arbor, MI: University of Michigan Press.

Muturi, N. (2003). Women's status in reproductive health decision-making: A communications approach. Journal of Development Communication, 14(1) 32-50

National Council for Population and Development (NCPD). (1998). Kenya demographic and health survey (KDHS). Nairobi: National Council for Population and Development and Macro International.

Nzau-Ombaka, K. (2001). Alternative access to abortion services under restrictive law: The Kenyan experience. In B. Klugman and D. Budlender (Eds.), Advocating for abortion access, eleven country studies. University of Witwatersrand, Women's Health Project. South Africa.

Patton, M. Q. (1990). Qualitative research and evaluation methods (2nd ed.), Newbury Park, CA: Sage.

Piotrow, P. T. \& Kincaid, D. L. (2001). Strategic communication for international health programs. In R. E. Rice and C. Atkin (Eds.), Public communication campaigns ( ${ }^{\text {rd }}$ ed., pp. 249-265). Thousand Oaks, CA: Sage.

Piotrow, P. T., Kincaid, D. L., Rimon, J. G., \& Rinehart, W. (1997). Health communication: Lessons from family planning and reproductive health. Westport, CT: Praeger.

Piotrow, P. T., Rimon II, J. G., Merritt, A. P., \& Saffitz, G. (2003). Advancing health communication: The PCS experience in the field. Baltimore: John Hopkins Bloomberg School of Public Health, Population Communication Services.

Piotrow, P. T., Treiman, K. A., Rimon, J. G., Yun, S. H., \& Lozare, B. V. (1994). Strategies for family planning promotion, Technical Paper Number 223, Washington, DC: World Bank.

Rogers, E. M. M. (1995). Diffusion of innovations (4th edition). New York: Free Press.

Rogo, K. O. (1989). Population trends and the status of population policy in Africa. Journal of Gynecology and Obstetrics, 4, 343-347.

Rogo, K. O. (1993). Induced abortion in sub-Sahara Africa. East Africa Medical Journal, 70,6.

Schoepf, G. B. (1997). AIDS, gender and sexuality during Africa's economic crisis. In G. Mikell (Ed.), African feminism. The politics of survival in sub-Saharan Africa. Philadelphia: University of Pennsylvania Press.

Steiner, M., Piedrahita, C., Joanis, C., Glover, L., \& Spruyt, A. (1994). Condom breakage and slippage rates among study participants in eight countries. International Family Planning Perspectives, $20,55-59$.

UNDP. (1993). Human development report. New York: Oxford University Press.

UNFPA. (1995). Report of the International Conference on Population and Development. UN Document. [On-line]. Available: http://www.unfpa.org=ICPD=ICPD.HTM

UNFPA. (1997). The right to choose: Reproductive rights and reproductive health. UNFPA Documents. [On-line]. Available: http://www.unfpa.org/SWP/SUMMARY.HTM 
Weijts, W. (1994, November). Responsible health communication: Taking control of our lives. The American Behavioral Scientist, 38, 257-270.

Westoff, C. \& Rodriguez, G. (1995). The mass media and family planning in Kenya. International Family Planning Perspective, 21(1).

Westoff, C. F. (1990). Is the KAP-Gap real? Population and development review, 14(2), 225-232.

Wimmer, R. D. \& Dominic, J. R. (1991). Mass media research: An introduction (3rd ed. ). Belmont, CA: Wadsworth.

Wolff, B., Blanc, A. K., \& Ssekamatte-Ssebuliba, J. (2000). The couple negotiation in unmet need for contraceptives and the decision to stop childbearing in Uganda. Studies in Family Planning, 31(2), 124-137.

World Bank. (1996). Improving reproductive health. The role of the World Bank. [On-line]. Available: http://www.worldbank.org/thml/hcovp/popu/repro.html

Yun, H., Govender, K., \& Mody, B. (2001). Factoring poverty and culture in HIV/AIDS campaigns: empirical support for audience segmentation. Gazette, 63(1), 73-90. 